\title{
Overlap and temporal variation in the diets of sympatric Antarctic and Subantarctic fur seals (Arctocephalus spp.) at Marion Island, Prince Edward Islands
}

\author{
Ryan R. Reisinger (1) ${ }^{a}$, Marietjie Landman ${ }^{\mathrm{b}}$, Nonkoliso Mgibantakaa, Malcolm J. Smale ${ }^{\mathrm{a}, \mathrm{c}}$, Marthán N. Bester ${ }^{\mathrm{d}}$, \\ P.J. Nico De Bruyn (1) ${ }^{d} \&$ Pierre A. Pistorius (1) ${ }^{a}$
}

\begin{abstract}
aDepartment of Zoology, DST/NRF Centre of Excellence at the Percy FitzPatrick Institute for African Ornithology, Nelson Mandela University, Port Elizabeth, South Africa; 'bCentre for African Conservation Ecology, Department of Zoology, Nelson Mandela University,

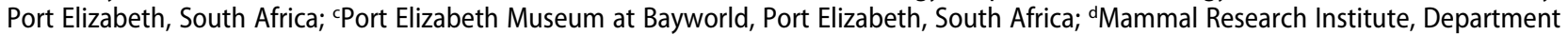
of Zoology and Entomology, University of Pretoria, Hatfield, South Africa
\end{abstract}

\begin{abstract}
Antarctic (Arctocephalus gazella) and Subantarctic (A. tropicalis) fur seals are important predators in the Southern Ocean. Marion Island (southern Indian Ocean) hosts the largest sympatric breeding populations of these two species. Environmental and population changes here over two decades may have influenced their diet and trophic interactions. To quantify diet, we analysed prey remains in scat samples from Antarctic (661 scats) and Subantarctic (750 scats) fur seals collected at Marion Island (2006-2010). We assessed diet composition over time and calculated dietary overlap. The diet of both species was dominated by fish prey (98.2\% and $99.4 \%$ of prey items), mainly myctophids. Antarctic fur seals consumed small numbers of penguins, cephalopods and crustaceans. In Subantarctic fur seal scats, crustaceans and cephalopods were rare and penguin remains were absent. The diets of the two species overlapped substantially (Pianka's index $=0.98$ ), however, small but significant differences in the relative proportions of prey were evident. Seasonal and annual diet changes suggest that their diet is similarly influenced by patterns of local prey availability and abundance. Despite substantial changes in the population size and trajectory of Antarctic and Subantarctic fur seals - which would be expected to influence trophic interactions between them - comparing our data to those from earlier studies (1989-2000) did not reveal significant long-term dietary changes in either species.
\end{abstract}

\section{KEYWORDS}

Prey; scats; foraging; marine mammal; pinniped; Southern Ocean

\section{ABBREVIATIONS}

$\mathrm{Cl}$ : confidence interval; PERMANOVA: permutational multivariate analysis of variance

\section{Introduction}

Fur seals of the genus Arctocephalus are major high trophic-level consumers in Southern Hemisphere oceans, with a diet consisting broadly of fishes, cephalopods and crustaceans (Arnould 2009). Two of the most abundant and widely distributed species - the Antarctic (Arctocephalus gazella) and Subantarctic (A. tropicalis) fur seal - number several million individuals (Arnould 2009; Forcada \& Staniland 2009) and represent an important component of these ocean ecosystems. Moreover, because changes in lower trophic levels are often reflected in the life histories and behaviour of such apex predators, fur seals can serve as useful bioindicators (e.g., Boyd \& Murray 2001; Forcada et al. 2005).

Populations of both Antarctic and Subantarctic fur seals have grown following historical near-extirpation (Bonner \& Laws 1964; Wickens \& York 1997). Further, contemporary environmental changes and inter-annual environmental variability appear to have influenced the diet and other population characteristics of these species, through changes in prey distribution and abundance (e.g., Guinet et al. 1994; Beauplet et al. 2005; Forcada et al. 2005; Lea et al. 2006; Hanson et al. 2009; Schwarz et al. 2013; Forcada \& Hoffman 2014; Oosthuizen et al. 2016; Wege, Etienne et al. 2016). It is therefore possible that the ecological influence of the species, as well as any putative competitive relationships between them, may be changing. Vital to understanding this is better knowledge of the diet of these two species.

Fur seals are central place foragers constrained to breed on land. Terrestrial environs are sparsely distributed in the Southern Ocean and fur seals are therefore concentrated at and around such (mostly island) breeding sites. Subantarctic fur seals breed on islands north of the Antarctic Polar Front, while Antarctic fur seals generally breed on Antarctic and sub-Antarctic islands south of the Antarctic Polar Front (Arnould 2009; Forcada \& Staniland 2009). The species breed in sympatry at three archipelagos:

CONTACT Ryan R. Reisinger ryan.r.reisinger@gmail.com @ Centre d'Etudes Biologiques de Chizé, UMR 7372 du CNRS-Université de La Rochelle, 79360 Villiers-en-Bois, France

(4) Supplemental data for this article can be accessed here. 
the Crozet Islands, Macquarie Island and the Prince Edward Islands (Forcada \& Staniland 2009). Marion Island (the larger of the two Prince Edward Islands), in the Indian Ocean sector of the Southern Ocean, hosts the largest sympatric breeding populations of Antarctic and Subantarctic fur seals, with abundance estimates (in 2004) of ca. 5800 Antarctic fur seals and 80000 Subantarctic fur seals (Hofmeyr et al. 2006). The Antarctic fur seal population has continued to increase in the last two decades, with pup production increasing by $13.8 \%$ per year from 1995 to 2004 (Hofmeyr et al. 2006), and by $4.0 \%$ per year from 2010 to 2013 (Wege, Etienne et al. 2016). The Subantarctic fur seal pup population increased by 5.2\% per year from 1995 to 2004 (Hofmeyr et al. 2006) but declined by $6.5 \%$ per year from 2004 to 2013 (Wege, Etienne et al. 2016). Reasons for the different pup production trajectories observed in the two species are speculative but may include densitydependent drivers on- and offshore. Central to any study assessing the potential for competition is identification of probable dietary overlap between putative competitors, and temporal flux thereof as the ecosystem changes.

Numerous dietary studies throughout the range of both these fur seal species have shown that there are substantial dietary differences seasonally, among populations and between species, and it appears that the specific diet of Antarctic and Subantarctic fur seals is largely determined by local conditions and prey availability (e.g., Bester \& Laycock 1985; Boyd et al. 1994; Iverson et al. 1997; Lea et al. 2002; Casaux et al. 2003; Reid et al. 2006; De Bruyn et al. 2009; Kernaléguen et al. 2012). This is amplified by the fact that the potential foraging range of individuals changes throughout their annual breeding season (De Bruyn et al. 2009; Wege, Tosh et al. 2016). Generally, however, Subantarctic fur seals feed mainly on myctophid fishes (Myctophidae: lanternfishes) (e.g., Robinson et al. 2002; Beauplet et al. 2004; Luque et al. 2007; De Bruyn et al. 2009), with the notable exception of Gough Island - the site of their largest population - where they feed primarily on cephalopods (Bester \& Laycock 1985). Antarctic fur seals also consume mainly myctophid fishes in the Indian and Pacific Ocean sectors of the Southern Ocean (Green et al. 1989; Robinson et al. 2002; Cherel et al. 2007; Lea et al. 2008), but in the Atlantic sector their diet is dominated by crustaceans (Antarctic krill [Euphausia superba]) (e.g., Reid 1995; Kirkman et al. 2000; Casaux et al. 2003; Daneri et al. 2005; Reid et al. 2006; Harrington et al. 2017). At Marion Island, four previous studies using faecal analysis (Klages \& Bester 1998; Makhado et al. 2008, 2013; De Bruyn et al. 2009) have shown that Antarctic and Subantarctic fur seals feed predominantly on fishes, mainly myctophids, and small amounts of cephalopods and crustaceans. These studies also highlighted a similar, albeit statistically different, diet for the two species, with both showing seasonal and annual variations.

Given the population changes of the two fur seal species at Marion Island (Wege, Etienne et al. 2016), and the potential for long-term dietary shifts concomitant with environmental change, as suggested elsewhere (e.g., Hanson et al. 2009; Tarroux et al. 2016), an evaluation of diet using more recent samples is valuable. In this study, we therefore analysed the faecal remains (hereafter 'scats') of Antarctic and Subantarctic fur seals at Marion Island, collected from 2006 to 2010 . This period immediately follows the onset of a decline in population numbers of the more abundant Subantarctic fur seals (Wege, Etienne et al. 2016), potentially driven by prey resource limitation, which would be expected to heighten resource partitioning between the two species. Using a large sample of scats, we identified prey remains which allowed us to infer the diet of these two species over the study period. Specifically, we: (1) quantify the inferred diet of the two species; (2) compare the diet composition within and between species, seasonally and annually; (3) calculate the dietary overlap between the two species to assess potential dietary partitioning; and (4) compare our findings to those of earlier studies at Marion Island.

\section{Methods}

Marion Island, the larger of the two islands comprising the Prince Edward Islands archipelago, is situated in the south-west Indian Ocean near the Subantarctic Front, between the Subtropical Convergence to the north and the Antarctic Polar Front to the south. Strong but dynamic ocean fronts and mesoscale eddies characterize the vicinity of the islands (Lutjeharms \& Ansorge 2008).

Scats were collected monthly from April 2006 to March 2010 at two long-term monitoring sites on Marion Island (Klages \& Bester 1998). Antarctic fur seal scats were collected at Watertunnel Beach $\left(46.96^{\circ}\right.$ S, $\left.37.74^{\circ} \mathrm{E}\right)$ and Subantarctic fur seal scats at Cape Davis Beach $\left(46.83^{\circ} \mathrm{S}, 37.75^{\circ} \mathrm{E}\right)$, where each species breeds exclusively (Wege, Etienne et al. 2016). Collected scats were individually frozen until processing. Each defrosted scat was broken up and washed through a $0.5 \mathrm{~mm}$ sieve under running water. Undigested prey remains were then separated and air-dried. Scats containing no prey remains were not included in further analyses, as these are very likely the scats of suckling pups (young of the year). Sagittal otoliths and lower beaks were used for the identification and quantification of fish and cephalopod prey, respectively. Fish have two sagittal otoliths, but we did not distinguish left and right otoliths; we assumed 
the number of otoliths represented the number of fish consumed (as in Makhado et al. 2008; Makhado et al. 2013). We identified prey items to the lowest taxonomic level possible using identification manuals (Hecht 1987; Smale et al. 1995) and by comparisons with a reference collection at the Port Elizabeth Museum, South Africa. Fish otoliths or cephalopod beaks that could not be identified because they were too eroded were not included in further analyses. Penguin feathers were collected but not identified to species level.

For analyses, we pooled cephalopod prey, crustacean prey and penguin prey because few or at times uncertain identifications were achieved at lower taxonomic levels in these categories. For analysis by season and year we also pooled fishes together. We grouped months into winter (April-September) and summer (October-March) seasons. 'Summer' scats represent the diet of breeding and moulting individuals of both species while 'winter' scats mainly represent lactating Subantarctic fur seal females. Subantartic fur seals breed ca. 2 weeks later and have a longer weaning period than Antarctic fur seals (300 days versus 110 days) (Kerley 1983; Hofmeyr et al. 2007). This pooling is consistent, and allows for comparison with previous studies of fur seal diet at Marion Island (Makhado et al. 2008, 2013).

Statistical analyses were conducted in the $R$ environment (R Core Team 2017). For each prey item or group, we calculated: (1) percentage frequency of occurrence $(\% F)$ - the number of scats in which a given prey item occurs, as a percentage of all scats; (2) percentage numerical abundance $(\% N)$ - the number of a given prey item in each scat, as a percentage of the number of all prey items in all scats. Confidence intervals for $\% F$ and $\% N$ were calculated by taking the $2.5 \%$ and $97.5 \%$ percentiles of 1000 bootstrap estimates. To compare the diets of the two species we used permutational multivariate analysis of variance (PERMANOVA) (Anderson 2001) and similarity percentages (Clarke 1993) based on Bray-Curtis dissimilarity. Using PERMANOVA we also tested whether there were seasonal differences in diet within and between species, as well as testing for changes in diet over time. For the latter analysis, we used only summer data. Following each comparison, we used a random forest model - fitted in the randomForest package (Liaw \& Wiener 2002) - to identify which prey contributed most to the observed differences. Diet overlap between the species was calculated using Pianka's index (Pianka 1973) with 10000 permutations, in the spaa package (Zhang 2016).

Finally, we compared our diet data to published data collected at the same sites during 1989-1995 (Klages \& Bester 1998) and 1996-2000 (Makhado et al. 2008; Makhado et al. 2013). Using a paired
Wilcoxon signed-rank test, we compared $\% F$ of prey which were identified to the same taxonomic level as in this study (excluding fish not identified to species level). The data were centred log-ratio transformed before the test, as they are compositional data (Van Den Boogaart \& Tolosana-Delgado 2013). A value for crustaceans was not reported for Subantarctic fur seals for 1996-2000. Penguin remains are not mentioned for the period 1989-1995, and are mentioned for 1996-2000, but not quantified.

\section{Results}

Between April 2006 and March 2010, we collected and analysed 661 Antarctic fur seal scats (386 during summer and 275 during winter) and 750 Subantarctic fur seal scats (504 during summer and 246 during winter) (Fig. 1). Based on these, respectively, we (a)

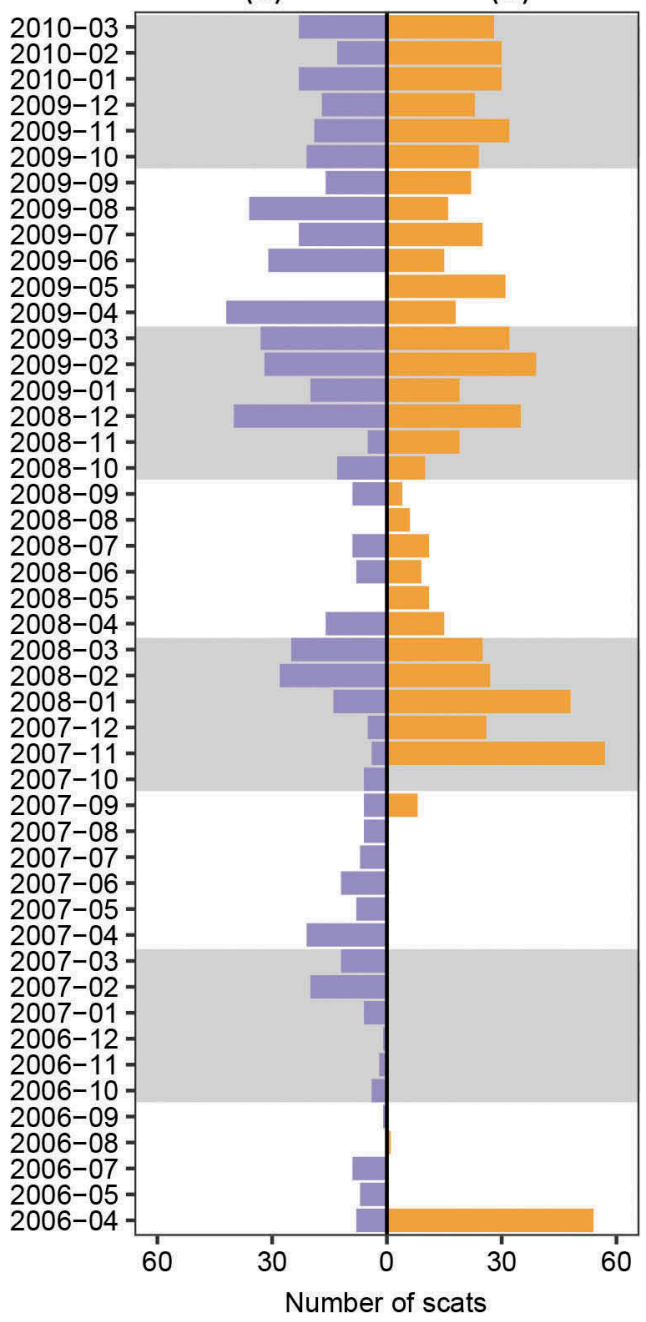

Figure 1. Histograms showing the number of (a) Antarctic and (b) Subantarctic fur seal scats collected at Marion Island from April 2006 to March 2010. For seasonal analyses, scats were pooled into 'summer' months (grey shaded blocks) (386 and 504 scats for Antarctic and Subantarctic fur seals, respectively) and 'winter' months (275 and 246 scats for Antarctic and Subantarctic fur seals, respectively). 
identified 9061 and 13654 individual prey items (Supplementary Table S1). Species accumulation curves indicated that we had collected sufficient scats to represent most prey in the diets of the two fur seals (Supplementary Fig. S1). In Antarctic fur seal scats we identified 28 prey types (cephalopods, crustaceans, penguins and 25 fish species); in Subantarctic fur seal scats we identified 30 (cephalopods, crustaceans and 28 fish species) (Table 1). Rank $\% \mathrm{~N}$ and $\% \mathrm{~F}$ were highly correlated in both species (Antarctic fur seals: $R_{S}=0.92$, Subantarctic fur seals: $\left.R_{S}=0.94\right)$. We therefore present only $\% \mathrm{~N}$ hereafter, except where the results were different.

Fishes dominated the diet of both species, accounting for $98.2 \%$ and $100 \%$ of prey $(\% N)$ in Antarctic and Subantarctic fur seals, respectively, and occurring in $75.9 \%$ and $99.5 \%(\% F)$ of scats (Table 1). The most important prey were nominally identified as having $\% N>10.0 \%$ (Table 1 ). These prey, four myctophids, had cumulative $\% N$ contributions of $75.2 \%$ (Antarctic fur seals) and 81.3\% (Subantarctic fur seals). Gymnoscopelus piabilis was the most abundant species in the diet of both fur seal species. While Antarctic fur seals consumed some crustaceans, penguins and cephalopods (all $<1.0 \% \mathrm{~N}$, but $4.7-11.2 \% \mathrm{~F}$ ), Subantarctic fur seals almost exclusively consumed fishes (Table 1).

Pianka's overlap index between the two species was high, at 0.97 (95\% CI $=0.916-0.995)$ and the diet of the two species was slightly, but significantly, different (PERMANOVA, $F_{1}=38.12, R^{2}=0.03$, $p=0.0001$ ). The abundance of four myctophids (all important prey) in the diet of each seal species contributed $72.8 \%$ of the difference between them (by similarity percentage). Based on the random forest model, the most influential prey discriminating the seals was Gymnoscopelus piabilis (normalized mean decrease in accuracy $=$ 58.38) (Supplementary Fig. S2). While G. piabilis were equally abundant in Antarctic (25.9\%) and Subantarctic (26.2\%) fur seal scats overall, they occurred more frequently in Subantarctic (77.3\%) than Antarctic fur seal (47.7\%) scats (Table 1). Overlap between the species was much higher in summer (Pianka's index $=0.98$; $95 \% \mathrm{CI}=0.97-1.00$ ) than in winter (Pianka's index $=0.89 ; 95 \% \mathrm{CI}=0.69-0.98)$, but diets were still significantly different in both summer (PERMANOVA, $F_{1}=20.40, R^{2}=0.02, p=0.0001$ ), and winter (PERMANOVA, $F_{1}=22.27, R^{2}=0.04$, $p=0.0001)$.

The summer and winter diet of Antarctic fur seals was significantly different (PERMANOVA, $\left.F_{1}=16.13, R^{2}=0.02, p=0.0001\right)$; the abundance of the myctophid Electrona carlsbergi was the most important difference according to the random forest model (normalized mean decrease in accuracy $=44.65$ )
(Fig. 2, Supplementary Fig. S2). The summer and winter diet of Subantarctic fur seals was also significantly different (PERMANOVA, $F_{1}=21.15$, $R^{2}=0.03, p=0.0001$ ), with most of the difference ascribed to the myctophids Metelectrona ventralis (normalized mean decrease in accuracy $=46.06$ ) and Protomyctophum tenisoni (42.28) (Fig. 2, Supplementary Fig. S2).

When considering summer data only, there was a significant effect of year on diet in both Antarctic fur seals (PERMANOVA, $F_{3}=7.81, R^{2}=0.06$, $p=0.0001)$ and Subantarctic fur seals (PERMANOVA, $F_{2}=11.14, R^{2}=0.04, p=0.0001$ ). Linear regression of summer $\% \mathrm{~N}$ against year showed the biggest changes in Protomyctophum tenisoni, which showed an increase in $\% N$ of $10.9 \pm 2.2$ and $12.4 \pm 8.4$ per year in Antarctic and Subantarctic fur seals, respectively; the change was only significant in Antarctic fur seals (Fig. 3, Supplementary Table S2). In Subantarctic fur seals, Gymnoscopelus fraseri decreased substantially $(-10.5 \pm 4.9 \% N)$, but not significantly (Fig. 3, Supplementary Table S2). In general, $\% N$ values for each prey were positively highly correlated between the two seals, although Electrona subaspera and Symbolophorus boops showed strong negative correlation (Supplementary Table S2). Diet overlap between the seals fluctuated over the three summers, with no clear pattern (Fig. 4). While all the PERMANOVA comparisons showed significant differences, the explanatory variables always explained only a small amount of the variation $\left(R^{2} \leq 0.06\right)$.

Antarctic fur seal diet in this study was not significantly different from that in 1996-2000 (Wilcoxon paired signed-rank test, $W=51$, $p=0.639)$ or $1989-1995(W=64, p=0.847)$. The same was true for Subantarctic fur seals $(W=31$, $p=0.340$ and $W=48, p=0.893$ ) (Supplementary Fig. S3).

\section{Discussion}

Antarctic and Subantarctic fur seals from Marion Island showed no significant long-term dietary changes despite substantial changes in their population sizes and trajectories over two decades. The diets of both species have consistently been dominated by fish, mainly myctophids. Their diets over this time frame were broadly similar with substantial overlap, but showed small significant differences in the relative proportions of prey. However, the diet of both species varied seasonally and annually, suggesting that their diet is similarly influenced by patterns of local prey availability and abundance. The scats of Antarctic fur seals indicate that they consume small proportions of penguins, cephalopods and crustaceans, while crustaceans and cephalopods were rare 
Table 1. Prey remains found in the scats of (a) Antarctic (Arctocephalus gazella) and (b) Subantarctic (A. tropicalis) fur seals, collected at Marion Island from April 2006 to March 2010. The most important prey, nominally identified as those with $\% N>10.0$, are shown in boldface.

\begin{tabular}{|c|c|c|c|c|c|c|c|c|}
\hline \multirow[b]{2}{*}{ Prey } & \multicolumn{3}{|c|}{$\% \mathrm{~F}^{\mathrm{a}}$} & \multicolumn{3}{|c|}{$\% \mathrm{~N}^{b}$} & \multicolumn{2}{|c|}{ Rank } \\
\hline & $\% \mathrm{~F}$ & $\mathrm{LCL}^{\mathrm{c}}$ & $\mathrm{UCL}^{\mathrm{d}}$ & $\% \mathrm{~N}$ & $\mathrm{LCL}$ & UCL & $\% \mathrm{~F}$ & $\% \mathrm{~N}$ \\
\hline \multicolumn{9}{|l|}{ (a) } \\
\hline Cephalopod & 4.7 & 3.2 & 6.4 & 0.4 & 0.2 & 0.5 & 14 & 15 \\
\hline Crustacean & 11.2 & 8.6 & 13.6 & 0.8 & 0.6 & 1.1 & 7 & 11 \\
\hline Penguin & 8.2 & 6.1 & 10.3 & 0.6 & 0.4 & 0.8 & 9 & 13 \\
\hline Fish $^{\text {e }}$ & 75.9 & 72.5 & 79.1 & 98.2 & 97.8 & 98.5 & & \\
\hline \multicolumn{9}{|l|}{ Bathylagidae } \\
\hline $\begin{array}{l}\text { Bathylagus unidentified } 1 \mathrm{sp} . \\
\text { Nototheniidae }\end{array}$ & 0.2 & 0.0 & 0.5 & 0.0 & 0.0 & 0.0 & 28 & 27 \\
\hline Dissostichus eleginoides & 1.2 & 0.5 & 2.1 & 0.2 & 0.1 & 0.3 & 19 & 17 \\
\hline Lepidonotothen larseni & 0.3 & 0.0 & 0.8 & 0.0 & 0.0 & 0.1 & 25 & 24 \\
\hline Notothenia squamifrons & 1.5 & 0.6 & 2.4 & 0.5 & 0.1 & 1.1 & 17 & 14 \\
\hline \multicolumn{9}{|l|}{ Myctophidae } \\
\hline Electrona antarctica & 5.6 & 3.9 & 7.4 & 1.4 & 0.7 & 2.6 & 11 & 9 \\
\hline Electrona carlsbergi & 32.7 & 29.2 & 36.5 & 9.7 & 7.9 & 11.8 & 3 & 5 \\
\hline Electrona unidentified $1 \mathrm{sp}$. & 0.3 & 0.0 & 0.8 & 0.0 & 0.0 & 0.1 & 24 & 25 \\
\hline Electrona subaspera & 7.9 & 5.8 & 10.0 & 2.7 & 1.8 & 4.1 & 10 & 7 \\
\hline Gymnoscopelus bolini & 10.4 & 8.0 & 12.9 & 2.0 & 1.5 & 2.6 & 8 & 8 \\
\hline Gymnoscopelus braueri & 0.2 & 0.0 & 0.5 & 0.0 & 0.0 & 0.0 & 26 & 28 \\
\hline Gymnoscopelus fraseri & 32.2 & 28.4 & 35.7 & 13.2 & 11.1 & 15.5 & 4 & 4 \\
\hline Gymnoscopelus nicholsi & 43.9 & 40.2 & 47.8 & 17.1 & 14.9 & 19.5 & 2 & 3 \\
\hline Gymnoscopelus piabilis & 47.7 & 43.6 & 51.4 & 25.9 & 22.5 & 29.3 & 1 & 1 \\
\hline Gymnoscopelus unidentified $1 \mathrm{sp}$. & 1.8 & 0.9 & 2.9 & 0.2 & 0.1 & 0.4 & 15 & 16 \\
\hline Krefftichthys anderssoni & 1.4 & 0.6 & 2.3 & 0.2 & 0.1 & 0.3 & 18 & 19 \\
\hline Lampichthys procerus & 0.5 & 0.0 & 1.1 & 0.0 & 0.0 & 0.1 & 22 & 23 \\
\hline Metelectrona ventralis & 11.8 & 9.4 & 14.2 & 3.4 & 2.3 & 4.6 & 6 & 6 \\
\hline Protomyctophum bolini & 1.7 & 0.8 & 2.7 & 0.2 & 0.1 & 0.3 & 16 & 18 \\
\hline Protomyctophum choriodon & 5.6 & 3.9 & 7.4 & 1.3 & 0.7 & 2.2 & 12 & 10 \\
\hline Protomyctophum tenisoni & 26.2 & 22.8 & 29.5 & 18.9 & 14.3 & 24.0 & 5 & 2 \\
\hline Symbolophorus boops & 4.7 & 3.2 & 6.4 & 0.8 & 0.5 & 1.1 & 13 & 12 \\
\hline \multicolumn{9}{|l|}{ Sternoptychidae } \\
\hline Maurolicus muelleri & 0.2 & 0.0 & 0.5 & 0.0 & 0.0 & 0.0 & 27 & 26 \\
\hline $\begin{array}{l}\text { Sternoptychidae unidentified } 1 \mathrm{sp} \text {. } \\
\text { Paralepididae }\end{array}$ & 0.5 & 0.0 & 1.1 & 0.1 & 0.0 & 0.1 & 23 & 22 \\
\hline Magnisudis atlantica & 1.2 & 0.5 & 2.1 & 0.1 & 0.0 & 0.2 & 20 & 21 \\
\hline \multicolumn{9}{|l|}{ Notosudidae } \\
\hline \multicolumn{8}{|l|}{ (b) } & 20 \\
\hline Cephalopod & 0.4 & 0.0 & 0.9 & 0.0 & 0.0 & 0.1 & 25 & 26 \\
\hline Crustacean & 0.1 & 0.0 & 0.5 & 0.0 & 0.0 & 0.0 & 30 & 30 \\
\hline Fish $^{\mathrm{e}}$ & 99.5 & 98.8 & 99.9 & 100.0 & 99.9 & 100.0 & & \\
\hline Bathylagidae & & & & & & & & \\
\hline Bathylagus gracilis & 0.1 & 0.0 & 0.4 & 0.0 & 0.0 & 0.0 & 28 & 29 \\
\hline $\begin{array}{l}\text { Bathylagus unidentified } 1 \mathrm{sp.} \\
\text { Nototheniidae }\end{array}$ & 0.7 & 0.1 & 1.3 & 0.0 & 0.0 & 0.1 & 24 & 25 \\
\hline Dissostichus eleginoides & 0.7 & 0.1 & 1.3 & 0.1 & 0.0 & 0.1 & 22 & 23 \\
\hline Notothenia squamifrons & 0.9 & 0.3 & 1.6 & 0.1 & 0.0 & 0.1 & 20 & 19 \\
\hline Myctophidae & & & & & & & & \\
\hline Electrona antarctica & 3.5 & 2.1 & 4.8 & 0.3 & 0.2 & 0.4 & 12 & 12 \\
\hline Electrona carlsbergi & 29.5 & 26.5 & 32.8 & 4.7 & 4.0 & 5.5 & 5 & 6 \\
\hline Electrona unidentified $1 \mathrm{sp}$. & 0.3 & 0.0 & 0.7 & 0.0 & 0.0 & 0.0 & 26 & 28 \\
\hline Electrona subaspera & 7.1 & 5.5 & 8.9 & 1.2 & 0.7 & 1.8 & 10 & 9 \\
\hline Gymnoscopelus bolini & 14.9 & 12.4 & 17.6 & 1.7 & 1.3 & 2.1 & 7 & 7 \\
\hline Gymnoscopelus braueri & 0.8 & 0.3 & 1.5 & 0.1 & 0.0 & 0.2 & 21 & 21 \\
\hline Gymnoscopelus fraseri & 42.0 & 38.4 & 45.6 & 16.9 & 14.1 & 19.9 & 3 & 4 \\
\hline Gymnoscopelus nicholsi & 69.3 & 66.3 & 72.7 & 21.2 & 19.4 & 23.3 & 2 & 2 \\
\hline Gymnoscopelus piabilis & 77.3 & 74.4 & 80.3 & 26.2 & 23.9 & 28.4 & 1 & 1 \\
\hline Gymnoscopelus unidentified $1 \mathrm{sp}$. & 1.5 & 0.7 & 2.4 & 0.1 & 0.1 & 0.2 & 16 & 14 \\
\hline Krefftichthys anderssoni & 1.5 & 0.7 & 2.4 & 0.1 & 0.0 & 0.2 & 14 & 16 \\
\hline Lampichthys procerus & 1.3 & 0.5 & 2.0 & 0.1 & 0.0 & 0.2 & 18 & 18 \\
\hline Metelectrona ventralis & 22.8 & 20.0 & 26.0 & 7.3 & 5.3 & 9.5 & 6 & 5 \\
\hline Protomyctophum bolini & 1.3 & 0.5 & 2.3 & 0.1 & 0.0 & 0.3 & 17 & 15 \\
\hline Protomyctophum choriodon & 8.4 & 6.5 & 10.3 & 1.2 & 0.7 & 1.8 & 8 & 8 \\
\hline Protomyctophum tenisoni & 30.0 & 26.7 & 33.2 & 17.0 & 13.9 & 20.3 & 4 & 3 \\
\hline Protomytophum bolini & 0.1 & 0.0 & 0.4 & 0.1 & 0.0 & 0.2 & 29 & 22 \\
\hline Symbolophorus boops & 4.5 & 3.1 & 5.9 & 0.5 & 0.3 & 0.6 & 11 & 11 \\
\hline Sternoptychidae & & & & & & & & \\
\hline Maurolicus muelleri & 1.5 & 0.7 & 2.4 & 0.1 & 0.0 & 0.2 & 15 & 17 \\
\hline $\begin{array}{l}\text { Sternoptychidae unidentified } 1 \text { sp. } \\
\text { Paralepididae }\end{array}$ & 1.1 & 0.4 & 1.9 & 0.1 & 0.0 & 0.1 & 19 & 20 \\
\hline Magnisudis atlantica & 2.7 & 1.6 & 3.9 & 0.2 & 0.1 & 0.3 & 13 & 13 \\
\hline $\begin{array}{l}\text { Paralepis unidentified } 1 \mathrm{sp} . \\
\text { Phosichthyidae }\end{array}$ & 0.7 & 0.1 & 1.3 & 0.0 & 0.0 & 0.1 & 23 & 24 \\
\hline $\begin{array}{l}\text { Photichthys argenteus } \\
\text { Notosudidae }\end{array}$ & 0.3 & 0.0 & 0.7 & 0.0 & 0.0 & 0.0 & 27 & 27 \\
\hline Scopelosaurus ahlstromi & 8.0 & 6.1 & 10.1 & 0.6 & 0.5 & 0.8 & 9 & 10 \\
\hline
\end{tabular}

${ }^{a}$ Percentage frequency occurrence. ${ }^{b}$ Percentage numerical abundance. ${ }^{c}$ Lower $95 \%$ confidence limit. ${ }^{d}$ Upper $95 \%$ confidence limit. ${ }^{e}$ Values shown here for fishes were calculated by pooling all fish prey together. 


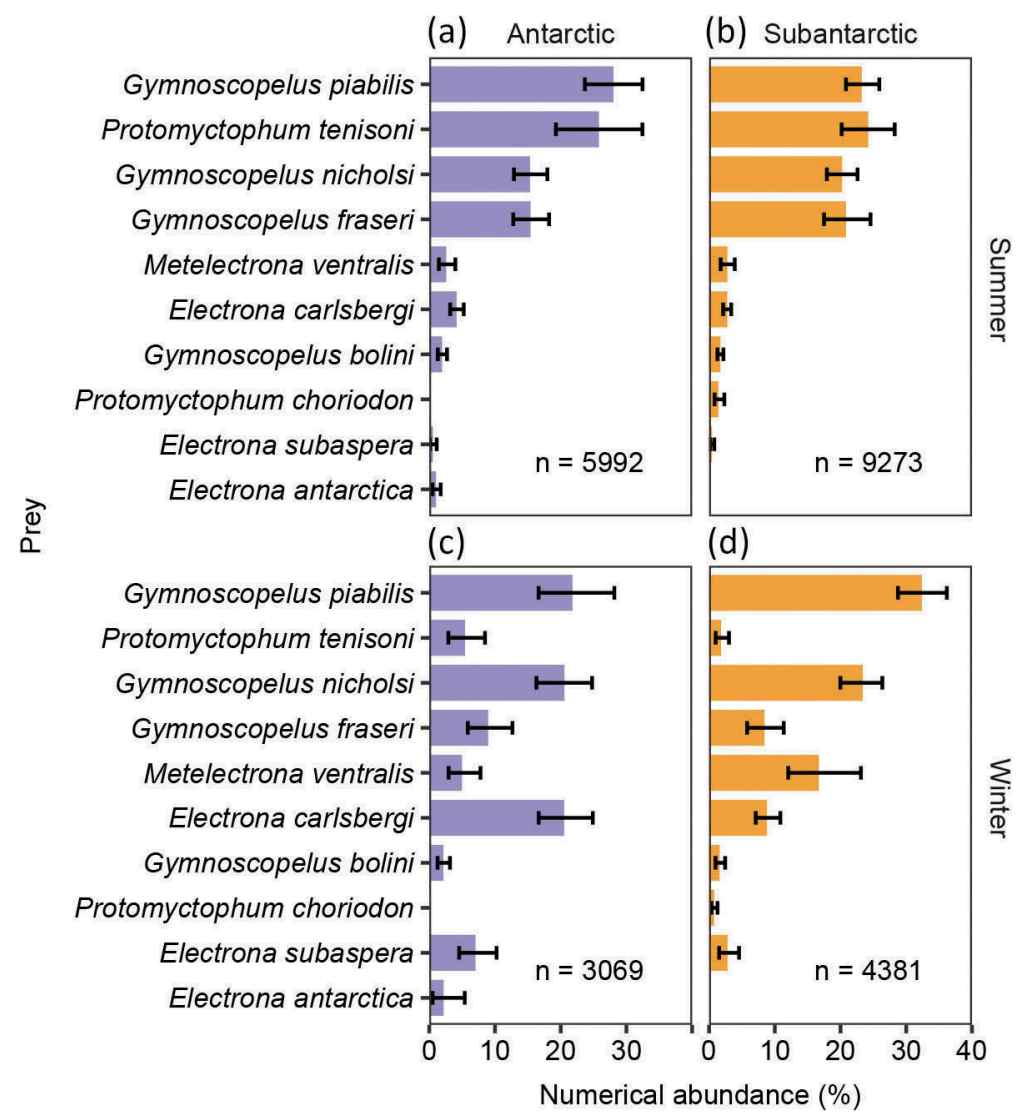

Figure 2. Numerical abundance (\%) of prey in the scats of $(a, c)$ Antarctic and (b, d) Subantarctic fur seals during (a, b) summer and $(c, d)$ winter at Marion Island. Sample sizes shown represent all prey items for each species and period, but only the 10 most abundant prey are shown (which corresponds approximately with prey contributing $\% N>1$ ). They are ordered by overall $\% N$ rank (see Table 1 for specific values). Error bars depict $95 \%$ confidence intervals.

(a) Antarctic

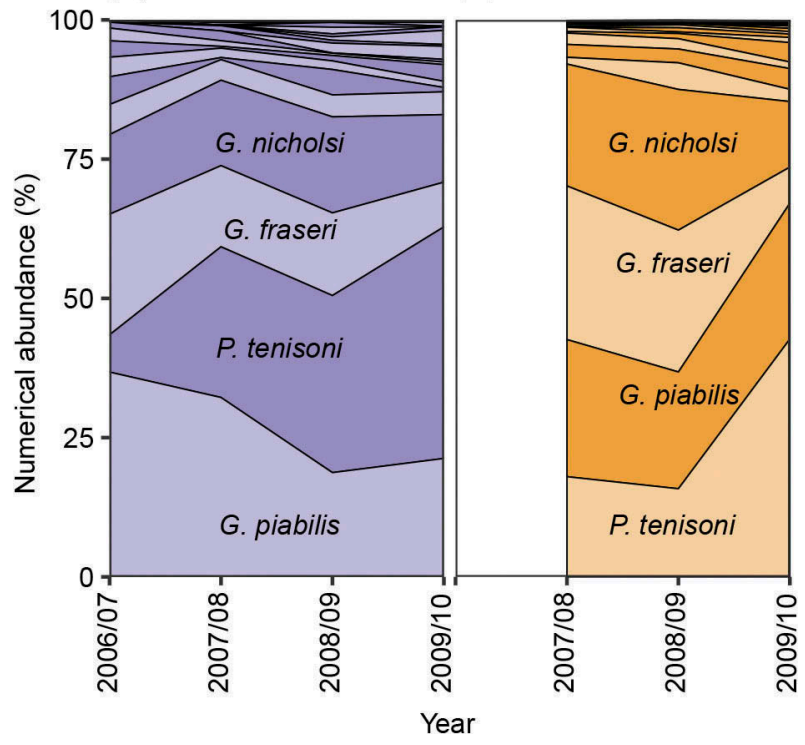

Figure 3. Changes in the summer diet composition (numerical abundance) of (a) Antarctic fur seals and (b) Subantarctic fur seals over four summers at Marion Island. For display, the four most abundant prey are labelled and they are ordered by summer $\% N$ rank (see Fig. 2). For Subantarctic fur seals, summer data were not collected in 2006/07. Linear regressions of the changes are shown in Supplementary Table S2.

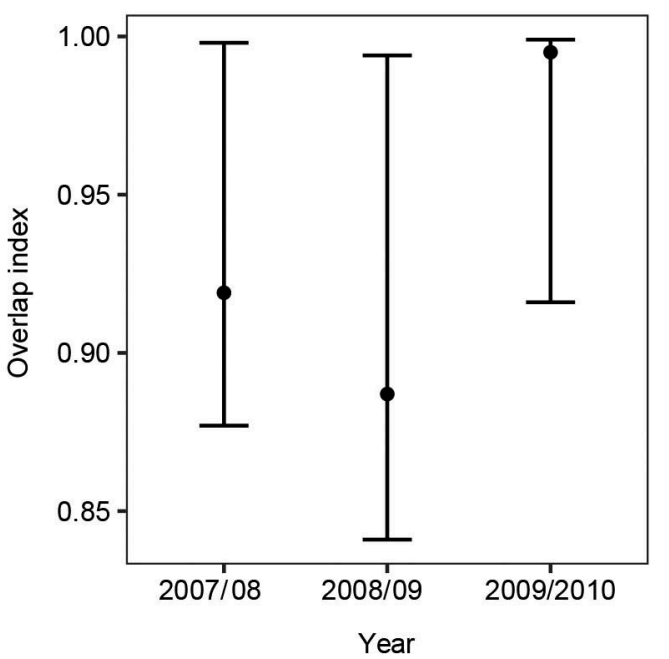

Figure 4. Diet overlap (Pianka's index) between Antarctic and Subantarctic fur seals over three summers at Marion Island. Error bars indicate $95 \%$ confidence intervals.

in Subantarctic fur seal scats and penguin remains were absent.

That we found no substantial changes in fur seal diet over the two decades between 1989 and 2010 is notable when considering the environmental changes 
which have occurred at Marion Island. Mean seasurface temperatures at Marion Island have increased by $1.4^{\circ} \mathrm{C}$ from 1949 to 2003 (Mélice et al. 2003) and there have been considerable changes in the population parameters of several predator species breeding at Marion Island (Crawford et al. 2009; Pistorius et al. 2011; Crawford et al. 2014; Oosthuizen et al. 2016; Wege, Etienne et al. 2016), presumably caused by changes in the abundance and distribution of prey. In the case of fur seals, density dependence and competition between the species may be expected to have influenced population parameters (Oosthuizen et al. 2016; Wege, Etienne et al. 2016). It is also interesting, therefore, that despite changes in the population size of Antarctic and Subantarctic fur seals over this time, there was not a marked change in diet or dietary overlap between the species.

Broadly, our results agree with previous dietary studies at Marion Island which have all found myctophids to be the dominant prey item in fur seal diets (Klages \& Bester 1998; Makhado et al. 2008; Makhado et al. 2013). Gymnoscopelus piabilis was generally the most abundant species and significant seasonal differences between species were due to changes in the proportions of several myctophids. Our results are also very similar to those from the nearest archipelago - the Crozet Islands - where Antarctic fur seals consume mainly G. piabilis and Subantarctic fur seals mainly G. fraseri and G. piabilis in summer (Cherel et al. 2007; Luque et al. 2007). The four most abundant prey in the diet of Marion Island fur seals were among the 11 most frequently occurring species in Southern Indian Ocean myctophid surveys (Koubbi et al. 2011). These four prey had overlapping occurrence in the species groups associated with the Polar Front and Subantarctic Front reported by Koubbi et al. (2011). The only species group containing the six most abundant prey was that associated with the Polar Front (Koubbi et al. 2011).

Interestingly, penguin feathers were not noted in the scats of either species in 1989-1995 (Klages \& Bester 1998) or for Subantarctic fur seals in 1996-2000 (Makhado et al. 2013), but appeared infrequently in Antarctic fur seal scats in 1996-2000 (Makhado et al. 2008). Penguin remains occurred in $8.2 \%$ of the Antarctic fur seal scats we examined, and none of the Subantarctic fur seal scats. Opportunistic predation of penguins has been reported in Antarctic as well as Subantarctic fur seals (Hofmeyr \& Bester 1993, and references therein) and land-based predation on king penguins (Aptenodytes patagonicus) by Antarctic fur seals first reported on Marion Island in 1986 persists (Hofmeyr \& Bester 1993; Haddad et al. 2015). Penguin remains were not abundant $(0.6 \%$ of prey) or very frequent ( $8.2 \%$ of scats) in Antarctic fur seal scats, but the large mass represented by an individual penguin (2.7-12.0 kg; Ryan \& Bester 2008) versus a myctophid (0.2 - $49.8 \mathrm{~g}$; Klages \& Bester 1998) means that penguins may contribute substantially to the diet of Antarctic fur seals, and this may lessen interspecific overlap.

We found significant seasonal and annual variations in prey proportions, as has been reported elsewhere (e.g., Bester \& Laycock 1985; Boyd et al. 1994; Iverson et al. 1997; Lea et al. 2002; Casaux et al. 2003; Reid et al. 2006; De Bruyn et al. 2009; Kernaléguen et al. 2012), indicating that the diets of both species are influenced by the local abundance and availability of prey. As Forcada \& Staniland (2009: 38) note, however, seasonal differences "are difficult to interpret because prey preference varies with age and sex of fur seals and the composition of the population in an area is very different within and outside of the breeding season." Nonetheless, our results (in the context of many other dietary studies) broadly support the notion that regional variation in fur seal diets is influenced by local conditions and prey abundance (Arnould 2009). Klages \& Bester (1998) briefly describe an overall picture: where the shelf is narrow, Antarctic and Subantarctic fur seals prey mainly on myctophids; where the shelf is broad, benthic and demersal fishes become more important. Where Antarctic krill is abundant, this is an important diet component along with its fish predators. Indeed, for Antarctic fur seals in the Atlantic sector of the Southern Ocean there is a strong negative correlation between the proportion of pelagic fish prey in their diet and the distance to shelf edge (Reid et al. 2006). That study also noted that seasonal sea surface temperature variability influenced the abundance of pelagic prey in the diet of Antarctic fur seals at South Georgia. While demersal-benthic fish may represent a consistent prey source over shelf areas, pelagic prey may be preferred when they are abundant in the foraging area, given the diving capabilities of fur seals. Marion Island does not have an extensive shelf and benthic and demersal prey should therefore be less important to fur seals here - indeed, the fish prey of fur seals at Marion Island were almost exclusively small, pelagic fishes. An exception was three nototheniid species that are usually benthic, but these were unimportant $(\% N \geq 0.5$, Table 1) and do have pelagic life phases (DeWitt et al. 1990).

The high dietary overlap between the species means there is potential for considerable competition between them (without necessarily being the case). For the period 1989-1995, Pianka's overlap index between the seals was 0.86 . This is lower than the overall overlap we report (0.97), and lower than any of the annual summer overlaps. However, the value does fall within the confidence interval of the lowest summer overlap that we report $(2008 / 09: 0.89,95 \%$ CI $=0.84-0.99)$, 
providing only limited support for an increase in dietary overlap. The pattern of diet overlap over time is consistent with a possible increase in competition due to population growth of the two species, but is not unambiguous evidence thereof.

Our results do show that dietary overlap is substantially higher during summer, when the foraging range of both species is more restricted and their atsea spatial segregation is likely lower (Wege, Tosh et al. 2016); any potential competition between the species will be greatest during this time. Potential competition between the two species could be minimized through the segregation of at-sea foraging grounds, as seems evident from recent tracking studies. Subantarctic fur seals forage primarily east and north-east or west and north-west of Marion Island and its neighbour Prince Edward Island (De Bruyn et al. 2009; Kirkman et al. 2016; Wege, Tosh et al. 2016). In contrast, winter tracking data show that Antarctic fur seals have a more southerly foraging distribution (Arthur et al. 2015; Arthur et al. 2016; Arthur et al. 2017), although there may be some overlap between the species to the east and northeast of Marion Island. Preliminary stable isotope analyses support this idea: Subantarctic fur seals had only slightly higher $\delta^{15} \mathrm{~N}$ values than Antarctic fur seals, indicative of a similar trophic level, but $\delta^{13} \mathrm{C}$ values of Subantarctic fur seals were significantly higher, suggesting more northerly foraging (Reisinger et al. 2016). This pattern is mirrored in results from the Crozet Islands, where Antarctic fur seals had lower $\delta^{13} \mathrm{C}$ values than Subantarctic fur seals, but similar $\delta^{15} \mathrm{~N}$ values (Cherel et al. 2007; Kernaléguen et al. 2012) and the foraging areas of the two species did not overlap (Bailleul et al. 2005). However, at Macquarie Island foraging areas were similar (Robinson et al. 2002).

It is also possible that diving predators segregate habitats vertically, by catching prey at different depths. This was not observed at Macquarie Island (Robinson et al. 2002). At the Crozet Islands Subantarctic fur seals dove deeper and longer than Antarctic fur seals, but Antarctic fur seals seemed to track the nycthemeral migration of their prey more closely (Luque et al. 2007). In that study, like our results, Antarctic and Subantarctic fur seals fed mainly on the same three myctophid species (Gymnoscopelus fraseri, G. piabilis and G. nicholsi - all important prey in our study), but their diets were distinguished by the proportion in which they consumed these prey (Luque et al. 2007). As Bailleul et al. (2005) point out, dietary and habitat use segregation in this pair of species may be driven by the comparatively higher energetic requirement of Antarctic fur seals, due to their much shorter lactation period, rather than through resource partitioning.

\section{Limitations and future research}

The comparison of our data to earlier data using $\% F$ was not as sensitive at it could be if the full data (i.e., prey composition per scat sample) were available for PERMANOVA comparison and annual comparisons. Stable isotope analysis of predator tissues would be a useful supplementary tool to investigate change over time. However, large numbers of scat samples can be collected compared to sampling predator tissues. Moreover, scat analysis has the important advantage of being able to better resolve the actual prey consumed by an individual than stable isotope analysis (especially if DNA analysis is used, e.g., EmamiKhoyi et al. 2016) and is the only method that can be used to deduce the size of prey (Tollit et al. 2010). However, the sex, age and sometimes even species of the animal which produced the scat is usually unknown. Scats mainly represent recent foraging, but bias is introduced by differential prey digestion and retention (Tollit et al. 2010); this bias can be expected to be similar in the two species, though, making comparisons between them useful. Therefore, we recommend the continued collection of scats of both species at the islands to monitor dietary change over time, and that future work should consider linkages between diet, abiotic conditions and prey abundance and distribution. Further, such work should be supplemented by stable isotope and tracking analyses.

\section{Acknowledgements}

We thank overwintering field biologists of the Mammal Research Institute who collected scats at Marion Island. We thank Ricardo Casaux and an anonymous referee for their comments on this manuscript.

\section{Disclosure statement}

No potential conflict of interest was reported by the authors.

\section{Funding}

This work was supported by the National Research Foundation (South Africa) under grant number SNA93071. RRR was supported by a National Research Foundation SANCOR post-doctoral fellowship (grant 94916).

\section{ORCID}

Ryan R. Reisinger (10) http://orcid.org/0000-0002-8933-6875 P.J. Nico De Bruyn (D) http://orcid.org/0000-0002-91149569

Pierre A. Pistorius (D) http://orcid.org/0000-0001-6561-7069 


\section{References}

Anderson M.J. 2001. A new method for non-parametric multivariate analysis of variance. Austral Ecology 26, 32-46.

Arnould J.P.Y. 2009. Southern fur seals: Arctocephalus spp. In F.P. William et al. (eds.): Encyclopedia of marine mammals. 2nd edn. Pp. 1079-1084. London: Academic Press.

Arthur B., Hindell M., Bester M., De Bruyn P.J.N., Trathan P., Goebel M. \& Lea M.-A. 2017. Winter habitat predictions of a key Southern Ocean predator, the Antarctic fur seal (Arctocephalus gazella). Deep-Sea Research Part II: Topical Studies in Oceanography 140, 171-181.

Arthur B., Hindell M., Bester M., Trathan P., Jonsen I., Staniland I., Oosthuizen W.C., Wege M. \& Lea M.-A. 2015. Return customers: foraging site fidelity and the effect of environmental variability in wide-ranging Antarctic fur seals. PLoS One 10, e0120888, doi:10.1371/journal.pone.0120888.

Arthur B., Hindell M., Bester M.N., Oosthuizen W.C., Wege M. \& Lea M.-A. 2016. South for the winter? Within-dive foraging effort reveals the trade-offs between divergent foraging strategies in a free-ranging predator. Functional Ecology 30, 1623-1637.

Bailleul F., Luque S., Dubroca L., Arnould J.P.Y. \& Guinet C. 2005. Differences in foraging strategy and maternal behaviour between two sympatric fur seal species at the Crozet Islands. Marine Ecology Progress Series 293, 273-282.

Beauplet G., Barbraud C., Chambellant M. \& Guinet C. 2005. Interannual variation in the post-weaning and juvenile survival of subantarctic fur seals: influence of pup sex, growth rate and oceanographic conditions. Journal of Animal Ecology 74, 1160-1172.

Beauplet G., Dubroca L., Guinet C., Cherel Y., Dabin W., Gagne C. \& Hindell M.A. 2004. Foraging ecology of Subantarctic fur seals Arctocephalus tropicalis breeding on Amsterdam Island: seasonal changes in relation to maternal characteristics and pup growth. Marine Ecology Progress Series 273, 211-225.

Bester M.N. \& Laycock P.A. 1985. Cephalopod prey of the sub-Antarctic fur seal, Arctocephalus tropicalis, at Gough Island In W.R. Siegfried et al. (eds.): Antarctic nutrient cycles and food webs. Pp. 551-554. Berlin: Springer.

Bonner W.N. \& Laws R.M. 1964. Seals and sealing In R. Priestleyet al. (eds.): Antarctic research. Pp. 163-190. London: Butterworths.

Boyd I.L., Arnould J.P.Y., Barton T. \& Croxall J.P. 1994. Foraging behavior of Antarctic fur seals during periods of contrasting prey abundance. Journal of Animal Ecology 63, 703-713.

Boyd I.L. \& Murray A.W.A. 2001. Monitoring a marine ecosystem using responses of upper trophic level predators. Journal of Animal Ecology 70, 747-760.

Casaux R., Baroni A., Arrighetti F., Ramón A. \& Carlini A. 2003. Geographical variation in the diet of the Antarctic fur seal Arctocephalus gazella.Polar Biology 26, 753-758.

Cherel Y., Hobson K.A., Guinet C. \& Vanpe C. 2007. Stable isotopes document seasonal changes in trophic niches and winter foraging individual specialization in diving predators from the Southern Ocean. Journal of Animal Ecology 76, 826-836.

Clarke K.R. 1993. Non-parametric multivariate analyses of changes in community structure. Australian Journal of Ecology 18, 117-143.

Crawford R.J.M., Dyer B., Upfold L. \& Makhado A. 2014. Congruent, decreasing trends of gentoo penguins and Crozet shags at sub-Antarctic Marion Island suggest food limitation through common environmental forcing. African Journal of Marine Science 36, 225-231.

Crawford R.J.M., Whittington P.A., Upfold L., Ryan P.G., Petersen S.L., Dyer B.M. \& Cooper J. 2009. Recent trends in numbers of four species of penguins at the Prince Edward Islands. African Journal of Marine Science 31, 419-426.

Daneri G.A., Carlini A.R., Hernandez C.M. \& Harrington A. 2005. The diet of Antarctic fur seals, Arctocephalus gazella, at King George Island, during the summerautumn period. Polar Biology 28, 329-333.

De Bruyn P.J.N., Tosh C.A., Oosthuizen W.C., Bester M.N. \& Arnould J.P.Y. 2009. Bathymetry and frontal system interactions influence seasonal foraging movements of lactating Subantarctic fur seals from Marion Island. Marine Ecology Progress Series 394, 263-276.

DeWitt H.H., Heemstra P.C. \& Gon O. 1990. Nototheniidae: notothens. In O. Gon \& P.C. Heemstra (eds.): Fishes of the Southern Ocean. Pp. 279-331. Grahamstown: JLB Smith Institute of Ichthyology.

Emami-Khoyi A., Hartley D.A., Paterson A.M., Boren L. J., Cruickshank R.H., Ross J.G., Murphy E.C. \& Else T.-A. 2016. Identifying prey items from New Zealand fur seal (Arctocephalus forsteri) faeces using massive parallel sequencing. Conservation Genetics Resources 8, 343-352.

Forcada J. \& Hoffman J.I. 2014. Climate change selects for heterozygosity in a declining fur seal population. Nature $511,462-465$.

Forcada J. \& Staniland I.J. 2009. Antarctic fur seal: Arctocephalus gazella. In F.P. Williamet al. (eds.): Encyclopedia of marine mammals. 2nd edn. Pp. 36-42. London: Academic Press.

Forcada J., Trathan P.N.T., Reid K. \& Murphy E.J. 2005. The effects of global climate variability in pup production of Antarctic fur seals. Ecology 86, 2408-2417.

Green K., Burton H.R. \& Williams R. 1989. The diet of Antarctic fur seals Arctocephalus gazella (Peters) during the breeding season at Heard Island. Antarctic Science 1, $17-324$.

Guinet C., Jouventin P. \& Georges J.-Y. 1994. Long term population changes of fur seals Arctocephalus gazella and Arctocephalus tropicalis on Subantarctic (Crozet) and subtropical (St. Paul and Amsterdam) islands and their possible relationship to El Niño Southern Oscillation. Antarctic Science 6, 473-478.

Haddad W.A., Reisinger R.R., Scott T., Bester M.N. \& De Bruyn P.J.N. 2015. Multiple occurrences of king penguin (Aptenodytes patagonicus) sexual harassment by Antarctic fur seals (Arctocephalus gazella). Polar Biology 38, 741-746.

Hanson N.N., Wurster C.M., Bird M.I., Reid K. \& Boyd I.L. 2009. Intrinsic and extrinsic forcing in life histories: patterns of growth and stable isotopes in male Antarctic fur seal teeth. Marine Ecology Progress Series $388,263-272$.

Harrington A., Daneri G.A., Carlini A.R., Reygert D.S. \& Corbalán A. 2017. Seasonal variation in the diet of Antarctic fur seals, Arctocephalus gazella, at 25 de Mayo/King George Island, South Shetland Islands, Antarctica. Polar Biology 40, 471-475.

Hecht T. 1987. A guide to the otoliths of Southern Ocean fishes. South African Journal of Antarctic Research 17, $150-158$. 
Hofmeyr G.J.G. \& Bester M.N. 1993. Predation on king penguins by Antarctic fur seals. South African Journal of Antarctic Research 23, 71-74.

Hofmeyr G.J.G., Bester M.N., Makhado A.B. \& Pistorius P. A. 2006. Population changes in Subantarctic and Antarctic fur seals at Marion Island. South African Journal of Wildlife Research 36, 55-68.

Hofmeyr G.J.G., Bester M.N., Pistorius P.A., Mulaudzi T.W., De Bruyn P.J.N., Ramunasi J.A., Tshithabane H.N., McIntyre T. \& Radzilani P.M. 2007. Median pupping date, pup mortality and sex ratio of fur seals at Marion Island. South African Journal of Wildife Research 37, 1-8.

Iverson S.J., Arnould J.P.Y. \& Boyd I.L. 1997. Milk fatty acid signatures indicate both major and minor shifts in the diet of lactating Antarctic fur seals. Canadian Journal of Zoology 75, 188-197.

Kerley G.I.H. 1983. Comparison of seasonal haul-out patterns of fur seals Arctocephalus tropicalis and A. gazella on Subantarctic Marion Island. South African Journal of Wildlife Research 13, 71-77.

Kernaléguen L., Cazelles B., Arnould J.P.Y., Richard P., Guinet C. \& Cherel Y. 2012. Long-term species, sexual and individual variations in foraging strategies of fur seals revealed by stable isotopes in whiskers. PLoS One 7, e32916, doi: 10.1371/journal.pone.0032916.

Kirkman S.P., Wilson W., Klages N.T.W., Bester M.N. \& Isaksen K. 2000. Diet and estimated food consumption of Antarctic fur seals at Bouvetoya during summer. Polar Biology 23, 745-752.

Kirkman S.P., Yemane D.G., Lamont T., Meÿer M.A. \& Pistorius P.A. 2016. Foraging behavior of Subantarctic fur seals supports efficiency of a marine reserve's design. PLoS One 11, e0152370 doi: 10.1371/journal. pone.0152370.

Klages N.T.W. \& Bester M.N. 1998. Fish prey of fur seals Arctocephalus spp. at Subantarctic Marion Island. Marine Biology 131, 559-566.

Koubbi P., Moteki M., Duhamel G., Goarant A., Hulley P. A., O’Driscoll R., Ishimaru T., Pruvost P., Tavernier E. \& Hosie G. 2011. Ecoregionalization of myctophid fish in the Indian sector of the Southern Ocean: results from generalized dissimilarity models. Deep-Sea Research Part II: Topical Studies in Oceanography 58, 170-180.

Lea M.A., Cherel Y., Guinet C. \& Nichols P.D. 2002. Antarctic fur seals foraging in the Polar Frontal Zone: inter-annual shifts in diet as shown from fecal and fatty acid analyses. Marine Ecology Progress Series 245, 281-297.

Lea M.A., Guinet C., Cherel Y., Duhamel G., Dubroca L., Pruvost P. \& Hindell M. 2006. Impacts of climatic anomalies on provisioning strategies of a Southern Ocean predator. Marine Ecology Progress Series 310, 77-94.

Lea M.A., Guinet C., Cherel Y., Hindell M., Dubroca L. \& Thalmann S. 2008. Colony-based foraging segregation by Antarctic fur seals at the Kerguelen Archipelago. Marine Ecology Progress Series 358, 273-287.

Liaw A. \& Wiener M. 2002. Classification and regression by randomForest. $R$ News $2,18-22$.

Luque S.P., Arnould J.P.Y., Miller E.H., Cherel Y. \& Guinet C. 2007. Foraging behaviour of sympatric Antarctic and Subantarctic fur seals: does their contrasting duration of lactation make a difference? Marine Biology 152, 213224.

Lutjeharms J.R.E. \& Ansorge I.J. 2008. Oceanographic setting of the Prince Edward Islands. In S.L. Chown \& P.W. Froneman (eds.): The Prince Edward Islands: land-sea interactions in a changing environment. Pp. 17-38. Stellenbosch: Sun Press.

Makhado A.B., Bester M.N., Kirkman S.P., Pistorius P.A., Ferguson J.W.H. \& Klages N.T.W. 2008. Prey of the Antarctic fur seal Arctocephalus gazella at Marion Island. Polar Biology 31, 575-581.

Makhado A.B., Bester M.N., Somhlaba S. \& Crawford R.J. M. 2013. The diet of the Subantarctic fur seal Arctocephalus tropicalis at Marion Island. Polar Biology $36,1609-1617$.

Mélice J.-L., Lutjeharms J.R.E., Rouault M. \& Ansorge I.J. 2003. Sea-surface temperatures at the sub-Antarctic islands Marion and Gough during the past 50 years. South African Journal of Science 99, 363-366.

Oosthuizen W.C., De Bruyn P.J.N., Wege M. \& Bester M. N. 2016. Geographic variation in Subantarctic fur seal pup growth: linkages with environmental variability and population density. Journal of Mammalogy 97, 347-360.

Pianka E.R. 1973. The structure of lizard communities. Annual Review of Ecology and Systematics 4, 53-74.

Pistorius P.A., De Bruyn P.J.N. \& Bester M.N. 2011. Population dynamics of southern elephant seals: a synthesis of three decades of demographic research at Marion Island. African Journal of Marine Science 33, 37-41.

R Core Team. 2017. R: a language and environment for statistical computing. Vienna: $\mathrm{R}$ Foundation for Statistical Computing.

Reid K. 1995. The diet of Antarctic fur seals (Arctocephalus gazella Peters 1875) during winter at South Georgia. Antarctic Science 7, 241-249.

Reid K., Davis D. \& Staniland I.J. 2006. Spatial and temporal variability in the fish diet of Antarctic fur seal (Arctocephalus gazella) in the Atlantic sector of the Southern Ocean. Canadian Journal of Zoology 84, 1025-1037.

Reisinger R.R., Grocke D.R., Lubcker N., McClymont E.L., Hoelzel A.R. \& De Bruyn P.J.N. 2016. Variation in the diet of killer whales Orcinus orca at Marion Island, Southern Ocean. Marine Ecology Progress Series 549, 263-274.

Robinson S.A., Goldsworthy S.G., Van Den Hoff J. \& Hindell M.A. 2002. The foraging ecology of two sympatric fur seal species, Arctocephalus gazella and Arctocephalus tropicalis, at Macquarie Island during the austral summer. Marine and Freshwater Research 53, 1071-1082.

Ryan P.G. \& Bester M.N. 2008. Pelagic predators. In S.L. Chown \& P.W. Froneman (eds.): The Prince Edward Islands: land-sea interactions in a changing ecosystem. Pp. 121-164. Stellenbosch: Sun Press.

Schwarz L.K., Goebel M.E., Costa D.P. \& Kilpatrick A.M. 2013. Top-down and bottom-up influences on demographic rates of Antarctic fur seals Arctocephalus gazella. Journal of Animal Ecology 82, 903-911.

Smale M.J., Watson G. \& Hecht T. 1995. Otolith atlas of southern African marine fishes. Grahamstown: JLB Smith Institute of Ichthyology.

Tarroux A., Lowther A.D., Lydersen C. \& Kovacs K.M. 2016. Temporal shift in the isotopic niche of female Antarctic fur seals from Bouvetøya. Polar Research 35, UNSP 31335, doi: 10.3402/polar.v35.31335.

Tollit D.J., Pierce G.J., Hobson K., Bowen W.D. \& Iverson S.J. 2010. Diet. In I.L. Boydet al. (eds.): Marine mammal ecology and conservation: a handbook of techniques. Oxford: Oxford University Press. 
Van Den Boogaart K.G. \& Tolosana-Delgado R. 2013. Analyzing compositional data with $R$. Berlin: Springer.

Wege M., Etienne M.P., Chris Oosthuizen W., Reisinger R. R., Bester M.N. \& De Bruyn P.J.N. 2016. Trend changes in sympatric Subantarctic and Antarctic fur seal pup populations at Marion Island, Southern Ocean. Marine Mammal Science 32, 960-982.

Wege M., Tosh C.A., De Bruyn P.J.N. \& Bester M.N. 2016. Cross-seasonal foraging site fidelity of
Subantarctic fur seals: implications for marine conservation areas. Marine Ecology Progress Series 554, 225-239.

Wickens P. \& York A.E. 1997. Comparative population dynamics of fur seals. Marine Mammal Science 13, 241-292.

Zhang J. 2016. spaa: species Association Analysis. R package version 0.2.2. https://CRAN.R-project.org/pack age $=$ spaa 